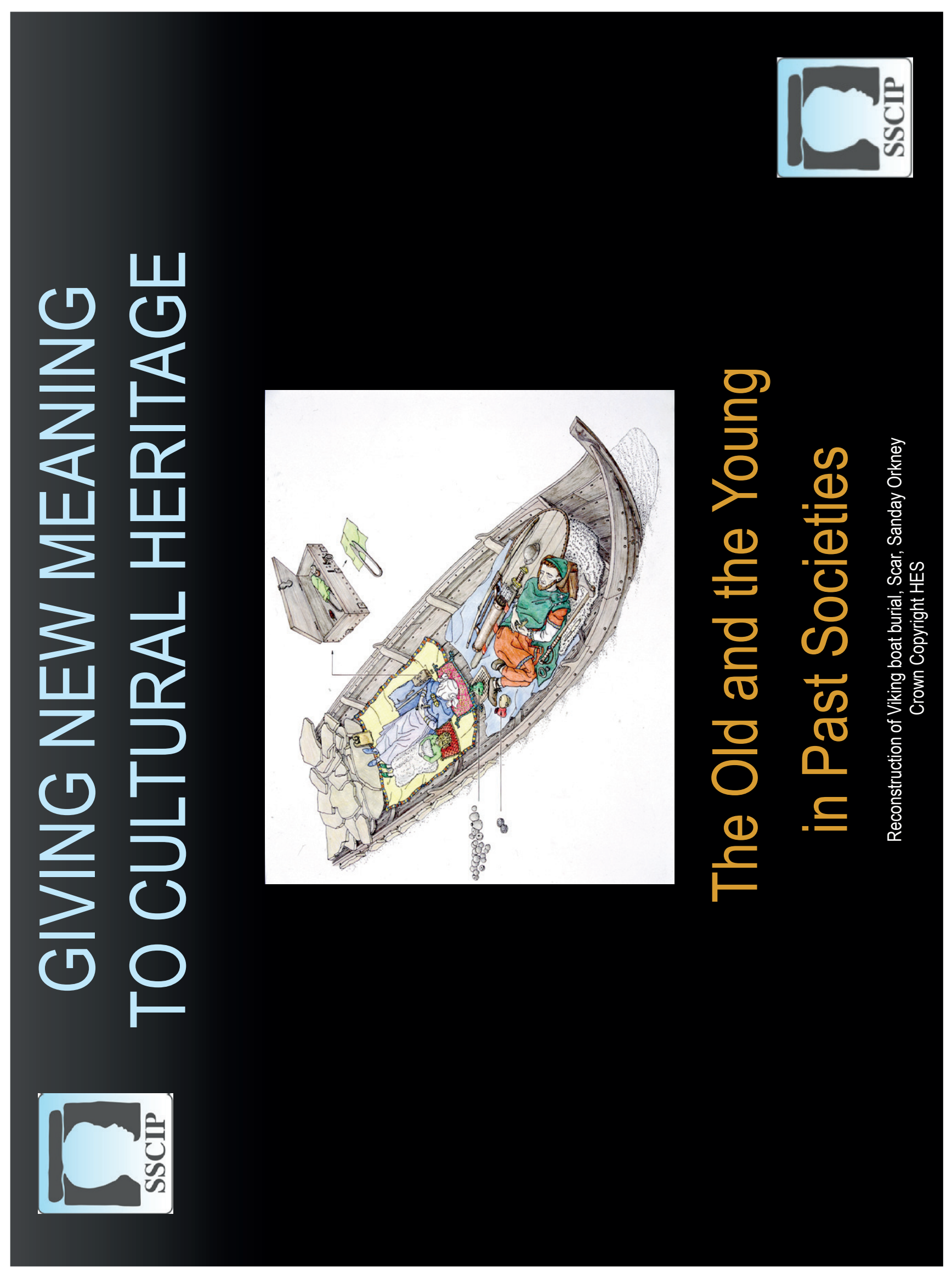

Title slide from the session held at the EAA annual meeting in Vilnius in 2016 which depicts the reconstruction of a Viking boat burial dating to AD 875-950 from Scar, Sanday, Orkney. The remains of a 10-11-year-old child were buried alongside an elderly woman of around seventy years towards the back of the boat, while a man aged approximately thirty years had been buried at the front (Crown@HES). 


\title{
1. Introduction - Across the Generations: The Old and the Young in Past Societies
}

\author{
GRETE LILLEHAMMER ${ }^{1}$ AND EILEEN MURPHY
}

Lillehammer, G. and Murphy, E. 2018 Across the Generations: The Old and the Young in Past Societies. AmS-Skrifter 26, 11-19, Stavanger. ISSN 0800-0816, ISBN 978-82-7760-181-6

Addresses: Museum of Archaeology, University of Stavanger, 4036 Stavanger, Norway';

Archaeology and Palaeoecology, School of Natural and Built Environment, Queen's University Belfast,

Belfast BT7 1NN, Northern Ireland². Emails: grete.lillehammer@uis.no; eileen.murphy@qub.ac.uk

'There is no foot too small or too old that it cannot leave an imprint on this world, past and present' (Gallou, this volume, page 70).

\section{Introduction}

In 2016, on behalf of The Society for the Study of Childhood in the Past (SSCIP), we organised a session, entitled 'Giving New Meaning to Cultural Heritage: The Old and the Young in Past Societies', at the annual conference of the European Association of Archaeologists (EAA) which took place in Vilnius, Lithuania. The idea for the event first materialised during the annual SSCIP conference in 2015 which took place in Chicago, USA, when we were both struck by the image shown on the front cover of the volume which depicts an elderly Aztec woman holding an infant and was presented during a paper by Hugo Pérez Trejo of the National School of Anthropology and History (ENAH), Mexico City. At the same time fellow SSCIP member, Povilas Blazevicius, informed us that the EAA conference for 2016 was to be held in his native Vilnius in Lithuania and invited us to come along. In other words, the usual story about how informal communications at conferences may result in something unexpected definitely happened in this instance. For a while we, the editors, had been playing with the idea of doing something together. Now we pondered on whether a quest for evidence of child and adult relationships would produce something new and promising on an interdisciplinary and transdisciplinary basis and, in particular, evidence of interactions between the young and old? We were curious as to how the EAA Scientific Committee and the archaeological environment in general would re- spond to the proposal and we were extremely pleased when the Committee accepted our application and SSCIP supported the event. The session was very enjoyable and inspiring, and many of the papers presented now appear within this book. The audience was highly engaged which enabled the topic to be brainstormed from a variety of different approaches.

So why did we choose to focus on the old and the young? Apart from having some fun with a fresh topic - to which we could both personally relate in our current capacity as parents and grandparent - we wished to explore approaches that could potentially both link or separate age distinctions in the human life course. There is no question that a familiar part of humanity is the bond of interrelationships between the older and younger generations in society. This is also an issue that is highly relevant in relation to the management, research and outreach of archaeological heritage - given the daily experience of observing active interactions between modern museum visitors, such as grandparents with their grandchildren. Due to various conditions in the modern world, however, such as climate change, migration, poverty, parental death, unrest and war, grandparents are often more or less key figures in their grandchildren's lives. Was this also the case in the past when most people are considered to have died generally at a younger age than today? How realistic is this question when posed in relation to the people of the past? We reached out with several questions - 
whether it is possible to find archaeological evidence of such interactions in the funerary record, in the chaîne opératoire associated with different forms of material culture, in spatial analyses, or in any other aspect of archaeological research. We also wished to explore how the archaeological evidence of such relationships is approached, integrated, and presented within cultural heritage management.

Adults overcrowd archaeological narratives about the human past and the manner in which the past is presented to a modern museum audience tells it all. In archaeological studies of the past, humans are often viewed as being adults in the prime of life and inadvertently 'male'. As an analytical category, the introduction of 'female' into archaeological discourses appeared with the growth of gender archaeology, and since then an explosion of research has also been undertaken on the archaeology of children over the past decade (Crawford 2017; Murphy 2017a). With some notable exceptions, however, the elderly are still largely invisible in archaeological narratives - even though ethnographic analogy clearly demonstrates that 'elders' were often viewed with particular respect due to the perceived wisdom associated with their longevity (see Appleby, this volume; see Maaranen and Buckberry, this volume). The inclusion of a wider spectrum of humanity within modern archaeological discourses has, however, resulted in an increase in studies of the human life course (e.g. Gilchrist 2012). It is clearly necessary to interconnect the different stages of the life course to enable us to gain a better understanding of the life experiences of individuals at different times for the duration of their lives.

A theme such as the 'young and the old' thus involves issues that also fall easily into the study of marginal, poorly visible, hidden and forgotten aspects of identities associated with phases of human life. Socio-cultural phenomena such as the integration and exclusion of individuals and age groups within a household or within a larger collective group of people raise general questions about how children and adults as collaborators interactively reproduce or innovate material culture, as well as the nature of the social dynamics that bind the young and the old together in life and in death. By focusing on relationships between different generations in the past, we hope to bring the elderly out from the shadows while also remembering that youngsters in the past would have interacted with adults beyond their parents - just as they do in the present. To arrive at some answers, and to advance knowledge about the young and the old, while exploring both the potentials and limitations in the evidence, we start with a brief history of some of the research that has paved the way for the current volume.

\section{A Short Research History}

Interests in the ages of the human life course arose with the impetus of gender and feminist archaeology in the 1970s and 1980s in the Scandinavian and AngloAmerican academy (Bertelsen et al. 1987; Lillehammer 1989; 2018; Crawford 1991; Gero and Conkey 1991; Sørensen 2000; Nelson 2004). It questioned a major gap in the understanding of the nature of age groups and their differing roles in society, but it focused mainly on the distinctions of sex and gender between female and male. Then in the 1980s symbolic and structural archaeology expanded the scientific way of approaching and interpreting the body of material remains in everything from artefacts, houses and rock art to settlement patterns in the archaeological evidence (Hodder 1982, cf. Moore 1987, fig. 3). In particular, investigations of the archaeologies of long-term history and contextual meaning (Hodder 1987a, b) and ethno-archaeological studies provided snapshots into social interactions and the relationships of power control and conflict, cultural transmission, and ritual participation especially amongst peoples in Eastern and Western Africa. The Marakwet in Kenya valued children as objects of wealth and stock. Elders gave unwanted household items away to younger members of their family. A conflict between what was traditional and modern existed between young men and the old because of emancipation (Moore 1987, 101, 103). The Dogon children and adults in Mali made use of facilities and spaces within compounds to a greater or lesser degree according to gender and age. Elderly male heads of the extended family were responsible for the daily and seasonal organisation of production, control, and distribution of collective labour products, and also controlled the rights and access to land and settlement (Lane 1987, 57). The Nri children in Nigeria underwent initiation rites performed by elders, that involved the use of a type of symbolic artefact - the scarification knife - to mark their faces, as they reached adulthood (Ray 1987, 75). These various pieces of information coming out of Africa indicate the nature of observations made about relationships between the young and old that were considered relevant to highlight at the time.

During the 1990s both children and elders, along with possibly more added gender distinctions, were still part of identities and activities rarely considered, 
however much some thought they should in order to identify 'sexual' divisions of labour (Hays-Gilpin and Whitley 1998, 141). Then in 1994 when Ruth Tringham focused on the history of place making and the continuity of place in the built environment, she elaborated on the struggle for power and tension between gender and age groups, such as children and elders. In her view the scales of depositional events that archaeologists excavate represent these moments of social actions, where individual actors are part of negotiations and dominance relations (see Tringham 2000). Later Roberta Gilchrist reflected on the identification of children, the middle-aged and the elderly in archaeological material. Importantly, she pointed to the constructions of biological and chronological age compared to the cultural variations in the number of life stages recognised across the life course, such as changes in fertility between immature and mature males and females, in contrast to more formal age statutes or grades of social hierarchies (Gilchrist 1999, 89-90, 105-8).

Following the initial fermentations between the 1970s and 1990s, the new millennium boosted the establishment of the archaeology of children and childhood (Crawford 2017). Even so today we acknowledge that the 'archaeological child' (Finlay 1997, 204) is not still part of 'the everyday practice' of doing archaeology (Cunnar and Högberg 2015, 76). Then what about the 'archaeological elderly'? In the decade between 2000 and 2010 researchers such as Stig Welinder (2001), Sam Lucy (2005), and Jo Appleby (2010) each took initiatives to advance an archaeology of old age. Sam Lucy suggests that the lack of archaeological interest is based on the modern assumption of the 'childish dependency', non-productiveness and 'infantilisation' of the elderly, which disregards the importance of their work and creates a loss of status in society (Hockey and James 1993, 5, 16-17; Lucy 2005, 57, 66). She found the opposite to be the case in the three-generational lifestyle model of cultural transmission and change, and particularly the model of social relationships of childcare, parenthood and grandparenthood in the extended family of traditional farming societies in Iceland (Edelstein 1983; Lucy 2005, 59-60, 65). This social organisation allowed for a very slow change in beliefs and practices between generations. With regards to Lucy's critique of modernity's negative attitude towards the elderly, a major question is therefore whether this phenomenon represents a modern development or not.

A significant contribution in this history of research is the volume edited by Shannon Lewis-Simpson (2008) entitled Youth and Age in the Medieval North which includes a series of papers that focus separately on the young and the old in past societies, including a paper by Philadelphia Ricketts (2008) on grandmothers and familial identity in Medieval Iceland. An important difference, however, is that most of the studies in our book have actively sought evidence for interactions across the generations. This is perhaps a reflection of the decade of research that has been undertaken in the archaeology of childhood since that time and may be an indication that the field is maturing and is now in a position to explore even more challenging research avenues.

\section{Life Span Stories Across the Generations}

A story narrated in the Norse Icelandic Sagas is worth mentioning here in the context of interactions across the generations. The legendary male poet Egill SkallaGrimsson, who was born around AD 910 and lived to the age of eighty years, established himself as a precocious Viking child since he composed poetry at the tender age of three years. He became a young hero, when he beheaded a man with a sword at the age of seven years. In the prime of adult life, he was a chief and a fierce warrior at sea and in battles, a man of grandeur and highly respected by all in Iceland. Then in old age, when his manly strength decayed and failed him, he became powerless. The servants kicked and scolded him, inside and outside the house, and the young generation was not only hostile, but also deeply alien to him (Yershova 2008). When he died a grand burial was staged, ideally a celebration of death to legitimise the rights of the family, but also a grand demonstration for the benefit of the gods and the rest of the world. Although not wishing to oversimplify the past, in the story of Egill Skalla-Grimsson we can identify the intimate struggle of power and change between generations, but also one which seems to contrast the grandmother's role in the reciprocal relationship between age and gender. In twelfth- and thirteenth-century Iceland the grandmother's social role and place involved name giving, fostering and heritage transmission to the grandchildren (Ricketts 2008). Compared to the role of the grandmother, Egill seems to have been unpopular as a grandfather.

The elderly also occupied prominent places within the Gaelic dynasties of Medieval Ireland, and many leaders appear to have been highly respected until they died. Aodh Ruadh Ó Domhnaill reigned as Taoiseach 
(leader) of Tír Conaill (modern County Donegal) for a period of forty-four years. He gained control of the lordship when he was thirty-four years old in AD 1461 and this remained with him (with the exception of several months in 1497 when he briefly abdicated in favour of his son who then died) until his death at the age of seventy-eight years old in AD 1505. Both the Annals of Ulster and the Annals of the Four Masters greatly sing his praises, with the latter stating:

The full moon of the hospitality and nobility of the North, the most jovial and valiant, the most prudent in war and peace, and of the best jurisdiction, law, and rule, of all the Gaels in Ireland in his time ... a man who may be justly styled the Augustus of the north-west of Europe (O'Donovan 1856, 1283; Donnelly and Murphy 2018, 114-18).

While Aodh Ruadh was from the upper classes of Gaelic society the law tracts provide insights about the treatment of the elderly in all levels of society, and it is clear children were expected to support their parents in old age, with the relationships between a mother and daughter and father and son being particularly highlighted (Dillon 1936, 129-30). The inclusion of the category - macc úar (cold son) - within the law tracts for a son who did not fulfil this duty is a clear indication that this support was not always provided (see Murphy and Donnelly, this volume).

From these brief excursions it would seem only natural that the built environment of family households among the living is a good place to start the search for some answers in relation to inter-generational relationships. The occupation of built spaces and inter-relationships between the people of a household can provide an indication as to how children and adults interact with the social and material worlds (Hutson 2015, 64-7). If we consider the contemporary attitudes shown to both Egill Skalla-Grimsson and Aodh Ruadh Ó Domhnaill as examples it is clear cultural differences may exist that are based on a society's views of human biological maturation and decline. Within Icelandic Viking society women appear to have retained status, whereas there are suggestions that elderly men may have been treated less favourably. Aodh Ruadh was respected in his later years, whereas Egill was not. The story of Egill is particularly informative since it charts his rise from childhood to the prime of life and subsequent decline in old age. Aodh Ruadh clearly retained status in his later years, but the brief abdication in favour of his son when he was seventy years old may hint at inter-generational tensions behind the scenes. The individual as an active agent transforms in terms of their roles, behaviours and responsibilities as a consequence of the ageing of the human body. Across the life course we see biological change and structural context that both constrain and enable actions of dependency, manipulation, emancipation, and control in the interactions between the young and old from the perspectives of both life and death. When considering the biological, social and cultural identities of the young and old the change of identity from during life to after death is an essential question. This is clearly evident in the tale of Egill Skalla-Grimsson in which the treatment he received as an elderly man is invisible in the manner of his funeral which harks back to the days when he was in the prime of his life.

We may ask how it is possible to link the social relationship of living household members with burial customs and commemoration of the young and elderly. What characterises the commemoration of a household, such as the family of Egill Skalla-Grimsson? Picking up a thread from the pre-SSCIP conference held in Southampton in 2006 (Lillehammer 2008), one approach is the general application of ancestor state models that governed households of an extended family. We may refer here to the Odal (Udal in Scottish dialect) rule model and to the first-principle origin of the first born (Helms 1998, 8; Lillehammer in prep.) and to social relationships representing collective burial and re-use of burial monuments (Parker Pearson 2003; Thäte 2007). Its background has been applied to the Viking Age (c. AD 750-1050) and onwards, but it may have been in use further back in time in Scandinavia and elsewhere. This rule confirmed the first-born son's rights, and sometimes also those of daughters (Sawyer and Sawyer 1993, 167), to family land and property by inheritance as well as a family's genealogical claim to the primary burial, such as the burial of the first settler interred in the farm mound of an estate (Iversen 2004). It also afforded daughters some protection when male relatives threatened their inheritance rights (Sawyer and Sawyer 1993, 167).

A notable majority of papers in the current volume explore evidence from the burial record to provide evidence of inter-generational interactions between the old and the young. While this aspect is also examined in her paper, Chrysanthi Gallou uses texts, iconography and material remains to investigate issues relating to the tutelage of the young by the old in matters including female health. She also examines evidence for the care of children by older members of society, and a topic of much relevance in the modern world, who may have looked after the children while their parents were 
working. She eloquently sums up the rationale for her research as follows:

... making the young and the old visible in the archaeological record and deciphering the interactions between the two extremes of the life course have ... the potential to advance our knowledge of the cultural, social and economic workings of the Late Bronze Age Aegean societies. This is because they allow a fuller appreciation of culturally and socially defined age constructions at that time, add to our understanding of the nature and operation of household and family structures, highlight aspects of economic life, professional training and apprenticeship, [and] underscore the role of the elderly in the support and socialisation of children (Gallou, this volume).

\section{Picking More Funerary Threads}

From both ethnographic and archaeological perspectives, burials and funerary structures appear as static items uncovered during excavation, but they are the result of social processes that occurred among the living (Ucko 1969, 276). The materiality of death is a matter of bodies, burials and beliefs (Fahlander and Oestigaard 2008), and ritual is linked frequently with burial (Insoll 2004, 11). Studies of the variation apparent in burial practices have identified as many as twenty different parameters that may have a material impact on burial ritual (Østigård 2006) and lead to change and reinvention of traditions (Oestigaard 2015). If we consider these parameters in the process of rites de passage and the transformative stages of the individual from alive, dead, and buried, to excavated material evidence (Lillehammer 1987; 1996, 98, fig. 69; in prep.), it is clear we are dealing with a complexity of mortuary idealisation in the ritual celebration of death in the past as well as with the archaeological recovery of the individual as a scientific specimen in the present. While searching for the hard facts of materiality that represents the young and old and interactions between them, what types of archaeological data and evidence would we expect to locate, identify and analyse in the archaeological burial record?

The papers in the volume have used an array of approaches based on evidence derived from the funerary record to understand more about the young and the old and the interactions that may have occurred between these two extremes of life. Perhaps the most obvious type of study is to look for evidence in the burial record which involves the physical placement of the young and old together in a burial, be it a simultaneous or contemporaneous deposit, and this is the method used by many of the authors in the current volume across time and space (Gallou, Le Roy et al., RebaySalisbury, Appleby, Denham et al., Zoega and Murphy and Donnelly). A number of studies have explored inter-generational relationships, seeking out potential grandparents and grandchildren or parents and children (e.g. Rebay-Salisbury, Appleby, Murphy and Donnelly). Others have addressed broader questions and considered whether or not children and adults were interred together in burial contexts, such as the collective burials of Late Neolithic France (Le Roy et al.), and what this might reveal about the nature of burial rites afforded at different stages of the life course. We discussed above how domestic structures have the potential to provide evidence for trans-generational interactions, but Guðný Zoëga uses evidence for multigenerational families found within cemeteries as an aid to interpreting the Medieval Icelandic household.

Several papers employ biostatistical approaches within their studies and the need for such methodologies to be reliable is an issue explored in the paper by Nina Maaranen and Jo Buckberry who demonstrate the potential of the Transition Method for raising the visibility of the old in past populations. Christine Cave and Marc Oxenham also focus largely on the older members of society and they consider two elderly women who may have held liminal status within Anglo-Saxon society for a multitude of reasons. It is quite often infants and young children who are treated differently in death and are sometimes viewed as 'liminal' (see e.g. Murphy and Le Roy 2017, 3) so it is fascinating to consider that those at the other extreme of the life course may have held similar status in certain past cultures. A further unifying factor that is rarely considered in archaeological discourses is the potential existence of a shared material culture by the young and the old in past societies; this is vividly illustrated by Chrysanthi Gallou who describes how clay 'feeding bottles' were sometimes placed as grave offerings in both the graves of children and the elderly in Late Bronze Age Aegean society.

Finally, in many past societies, older women interfaced with the newly born through their roles as midwives - as depicted on the front cover of this volume for Aztec society - but they also interfaced with the dead. In Medieval Britain and Ireland, for example, it is generally considered that older women were those who dressed the dead and prepared them for burial and the afterlife (see e.g. Gilchrist 2008; Murphy 2017b). Indeed, in her paper Chrysanthi Gallou, 
provides a poignant description of a scene on a terracotta sarcophagus from Tomb 22 in the cemetery at Tanagra in which two elderly women gently lower the shrouded corpse of a child into a wooden coffin with the aid of a stretcher-like bier. The transitions at the beginning and ending of life are clearly places where we might find evidence for powerful interconnections between the young and the old.

\section{On the Look Out for the Young and Old Across the Generations}

Evidence from both the modern world and ethnography make it clear that the old and the young frequently interact in a myriad of ways in daily life. It is challenging to find evidence of such daily interactions in the archaeological record and indeed it is evident from the discussions above that we are largely dependent on funerary evidence to capture glimpses of these connections. So how are we to address the missing empirical evidence in the future? Are there any links or limits set by universals or variations in the ritual evidence that could lead us further into a terrain that is difficult to traverse? It is evident that bioarchaeologists are striving ahead to improve methods of age determination and statistical approaches and the more frequent adoption of rigorous archaeothanatological studies may also prove fruitful. But will it always prove necessary to rely on the funerary record for such evidence or is there scope to undertake broader studies focusing on iconography, texts and material culture following the example of Chrysanthi Gallou in this volume? Now that children and the elderly are considered viable subjects of research we would like to see more consideration of the nature of the interactions that may have existed between these groups; this will help us to continue to make the people of the past all the more human and real.

\section{Overview of the Volume}

In the following section we provide a brief summary of the papers included in the volume which has been broadly structured in chronological order and includes case studies from across Europe.

In their paper Mélie Le Roy and colleagues examine the variety of structures used for collective burial in Late Neolithic France to determine if all members of a population are represented within the different burial types. Using statistical analysis of osteological data, they investigate whether age-based funerary selection was in place and if children were buried in the same locations as adults. They also examine if certain preadult age groups were excluded from particular sites. They identified four major types of funerary selection based on the age-at-death of immature individuals within the Late Neolithic French collective burials - a normal mortality distribution (Type 1); a profile in which individuals less than five years are underrepresented (Type 2); an under-representation of children less than five years and an over-representation of those greater than five years (Type 3) and an absence of children less than five years with a significant overrepresentation of one or more other age groups (Type 4). Differences in the overall trends and chronologies were observed between northern and southern France that were interpreted as an indication of differing cultural practices.

Katharina Rebay-Salisbury explores burials that contain the remains of two or more people from the contemporary Únětice and Unterwölbing cultures of Early Bronze Age Austria. She reviews the social relations expressed through such burials, with the aim of better understanding gender relations, family structures and social organisation. She particularly focuses on motherchild relationships, including women who died during pregnancy, to explore how such individuals were treated by their societies in death. Differences in the trends are considered suggestive that the northern Unětice culture placed more emphasis on family relationships and emotional connections, whereas the categorisation as man or woman was central to the funerary rite of the southern Unterwölbing culture. Jo Appleby's paper leads on from that of the previous author and also centres around Early Bronze Age Austrian burials but in this case the focus is on grandparents and grandparenting. She positions the research with a discussion of the reasons why archaeological studies have largely ignored the old and why considerations of grandparents are largely absent from such narratives. She explores anthropological and ethnographical approaches to grandparenting that are of potential relevance for understanding the role of such individuals in prehistoric societies and considers potential methodologies for identifying evidence for grandparents in the archaeological record. Using demographic data obtained from burials she considers how grandparents may have contributed to the care of children and attempts to identify potential grandparent/grandchild relationships.

Chyrsanthi Gallou notes the adult-centric focus of much of the scholarship on age and gender in prehistoric Greece, with the resultant neglect of the children 
and the elderly. Her paper uses an interdisciplinary methodology to systematically study the available material remains of Minoan and Mycenaean societies of the Late Bronze Age Aegean to assess the evidence for childhood and old age during this period. She interrogates a range of sources including funerary contexts, as well as a rich array of iconographic sources and textual references and ethnographic analogies. She examines evidence for the interactions that occurred between the younger and older segments of the population both in life - alloparenting and later-life support traditions, apprenticeships and socialisation, and healing - as well as death.

In their chapter Sean Denham, Mari Høgestøl and Grete Lillehammer present research conducted as part of the BEVARES (Biological EnVironmental and Archaeological interdisciplinary RESearch on lifecourse, material and materiality in human depositions) programme at the Museum of Archaeology, University of Stavanger. They examine cremated bone material of Bronze Age and Iron Age date from Rogaland county in southwestern Norway in an effort to find evidence of interactions between the younger and older members of these groups. While atypical burials containing the remains of these cohorts are known from Norway they are rare in more usual burials. They also compare the demographics revealed in their data to an earlier study of burials from Eastern Norway (Holck 1986) and find some interesting differences in trends; while the young are well represented in western burials they occur less frequently in the eastern burials and the elderly are poorly represented in both regions. They conclude by suggesting several further lines of enquiry and urge that more effort is made to find evidence of the inevitable interactions that would have existed between the young and the old in past societies.

The paper of Christine Cave and Marc Oxenham focuses on liminality of the elderly; a feature that is often considered in discussions of child burials. Their study examines the burials of two elderly AngloSaxon women in the cemetery of Mill Hill, Deal, Kent in England. They consider these two individuals to display multiple liminalities, associated with their advanced age, gendered identities and potential religious beliefs. On the basis of osteological, funerary and chronological evidence they advance the theory that the women represented the last burials in the cemetery, perhaps long after it had gone out of general use. They suggest these women were the last pagans in their community at a time when Christianity had become the dominant religion.
Guðný Zoëga's chapter examines early Christian household cemeteries from the Skagafjörður region of North Iceland. The household cemeteries included individuals of both sexes and all ages, with the very young and the elderly being particularly represented. She examines the osteological and burial data to determine how these age groups may have been perceived and to what extent they may have interacted. She discusses how the information derived from the burials can add to the predominantly philological and historical discussions on the nature, composition and social interactions of the Medieval Icelandic household. She considers the implications that evidence for multi-generational families found in the cemeteries has for our understanding of the Medieval Icelandic household, suggesting that intergenerational transference of knowledge and shared life experiences would have facilitated household social cohesion and a sense of familial identity.

The paper of Eileen Murphy and Colm Donnelly examines contemporary multiple interments in Medieval Christian burial grounds in Ireland. They review the demographic combinations and funerary practices apparent in such burials as well as information in contemporary historical accounts to gain insights concerning potential social relationships that may have existed between those interred together in each grave. They sub-divide the burials into those of adults only, juveniles only and those of an adult and child. Most burials comprised a middle-aged or older adult and a child and it is possible that some of these were grandparents and grandchildren. The findings from Ireland are also compared to those of studies of similar burials in Anglo-Saxon England and different demographic trends were evident.

The final paper of the volume, by Nina Maaranen and Jo Buckberry, focuses on the determination of age-atdeath in adult populations. It starts with a review of age estimation methods in current widespread use and discusses the issues that affect these approaches and lead to a general invisibility of the elderly in archaeological populations. It introduces a biostatistical technique - Transition Analysis - an approach that generates individual age estimates and facilitates better differentiation between individuals and age groups. The study involves a test of the reliability of the methods devised by Boldsen and colleagues (2002) on an Early Modern (1839-1937) Finnish population of known age and sex held by the Finnish Natural History Museum in Helsinki. It demonstrates the reliability of the approach, and the authors urge that further research is under- 
taken in biostatistical methods to not only improve ageing techniques but bring greatly needed attention to the elderly, which will then open up broader narratives on past society, including family dynamics and their interaction with the young - the very topics that lie at the heart of this volume.

\section{References}

Appleby, J. E. P. 2010. Why we need an archaeology of old age, and a suggested approach. Norwegian Archaeological Review 43, 145-68.

Bertelsen, R., Lillehammer, A. and Næss, J.-R. (eds.) 1987. Were They All Men? An Examination of Sex Roles in Prehistoric Society (AmS-Varia 17). Stavanger: Arkeologisk museum i Stavanger.

Boldsen J., Milner, G., Konigsberg, L. and Wood, J. 2002. Transition analyses: a new method for estimating age from skeletons, pp. 73-106 in Hoppa, R. W. and Vaupel, J. W. (eds.), Palaeodemography: Age Distributions from Skeletal Samples. Cambridge: Cambridge University Press.

Crawford, S. 1991. When do Anglo-Saxon children count? Journal of Theoretical Archaeology 2, 17-24.

Crawford, S. 2017. SSCIP: The first 10 years. Childhood in the Past 10, 10-15.

Cunnar, G. E. and Högberg, A. (eds.) 2015. The child is now 25 - A short introduction to a special issue. Childhood in the Past 8, 75-7.

Dillon, M. 1936. The relationship of mother and son, of father and daughter, and the law of inheritance with regard to women, pp. 129-79 in Thurneysen, R., Power, N., Dillon, M., Mulchrone, K., Binchy, D. A., Knoch, A. and Ryan, J. (eds.), Studies in Early Irish Law. Dublin: Royal Irish Academy.

Donnelly, C. J. and Murphy, E. M. 2018. Violence in later medieval Ireland: the osteoarchaeological evidence and its historical context, pp. 108-28 in Campbell, E., Fitzpatrick, E. and Horning, A. (eds.), Becoming and Belonging in Ireland AD c. 1200-1600: Essays in Identity and Cultural Practice. Cork: Cork University Press.

Edelstein, W. 1983. Cultural constraints on development and vicissitudes of progress, pp. 48-81 in Kessel, F. S. and Siegel, A. W. (eds.), The Child and Other Cultural Inventions. New York: Praeger.

Fahlander, F. and Oestigaard, T. 2008. The materiality of death. Bodies, burials, beliefs, pp. 1-16 in Fahlander, F. and Oestigaard, T. (eds.), The Materiality of Death. Bodies, Burials, Beliefs (BAR International Series 1768). Oxford: Archaeopress.

Finlay, N. 1997. Kid knapping: the missing children in lithic analyses, pp. 102-12 in Moore, J. and Scott, E. (eds.), Invisible People and Processes. Writing Gender and Childhood into European Archaeology. London: Leicester University Press.

Gero, J. M. and Conkey, M. W. 1991 (eds.). Engendering Archaeology. Women and Prehistory. Oxford: Basil Blackwell.

Gilchrist, R. 1999. Gender and Archaeology Contesting the Past. London: Routledge.

Gilchrist, R. 2008. Magic for the dead? The archaeology of magic in Later Medieval burials. Medieval Archaeology 52, 119-59.
Gilchrist, R. 2012. Medieval Life: Archaeology and the Life Course. Woodbridge: The Boydell Press.

Hays-Gilpin, K. and Whitley, D. S. 1998. Reader in Gender Archaeology. London: Routledge.

Helms, M. W. 1998. Access to Origins. Affines, Ancestors and Aristocrats. Austin: University of Texas Press.

Hodder, I. (ed.) 1982. Symbolic and Structural Archaeology. Cambridge: Cambridge University Press.

Hodder, I. (ed.) 1987a. Archaeology as Long-term History. Cambridge: Cambridge University Press.

Hodder, I. (ed.) 1987b. The Archaeology of Contextual Meaning. Cambridge: Cambridge University Press.

Hockey, J. and James, A. 1993. Growing up and Growing Old: Ageing and Dependency in the Life Course. London: Sage.

Holck, P. 1986. Cremated Bones: A Medico-anthropological Study of an Archaeological Material on Cremation Burials (Antropologiske skrifter no. 1). Oslo: Anatomisk Institutt, Universitet i Oslo.

Hutson, S. R. 2015. Method and theory for an archaeology of age, pp. 53-72 in Coşkunsu, G. (ed.), The Archaeology of Childhood (IEMA Proceedings 4). Albany: State University of New York Press.

Insoll, T. 2004. Archaeology, Ritual, Religion. London: Routledge.

Iversen, F. 2004. Eiendom, Makt og Statsdannelse: Kongsgårder og Gods $i$ Yngre Jernalder og Middelalder. Bergen: Universitetet i Bergen.

Lane, P. 1987. Recording residues of the past, pp. 54-62 in Hodder, I. (ed.), Archaeology as Long-Term History. Cambridge: Cambridge University Press.

Lewis-Simpson, S. (ed.) 2008. Youth and Age in the Medieval North (The Northern World 42). Leiden: Brill.

Lillehammer, G. 1987. Looking for individuals in archaeological burial data, pp. 79-87 in Bertelsen, R., Lillehammer, A. and Næss, J.-R. (eds.), Were They All Men? An Examination of Sex Roles in Prehistoric Society (AmSVaria 17). Stavanger: Arkeologisk museum i Stavanger.

Lillehammer, G. 1989. A child is born. The child's world in archaeological perspective. Norwegian Archaeological Review 22, 91-105.

Lillehammer, G. 1996. Død og grav. Gravskikkpå Kvassheimgravfeltet, Hå $i$ Rogaland, SV Norge. Extended English summary. (AmS-Skrifter 13). Stavanger: Arkeologisk museum i Stavanger.

Lillehammer, G. 2008. Transforming images: Exploring powerful children. Childhood in the Past 1, 94-105.

Lillehammer, G. 2018. The history of the archaeology of childhood, pp. 38-51 in Crawford, S., Hadley, D. and Shepherd, G. B. (eds.), The Oxford Handbook of the Archaeology of Childhood. Oxford: Oxford University Press.

Lillehammer, G. in prep. Mind the gap of child burial. Papers from the Reykholt Conference 2016, Island. To be published in UBAS, University of Bergen, Bergen.

Lucy, S. 2005. The archaeology of age, pp. 43-67 in DiazAndreu, M., Lucy, S., Babić, S. and Edwards, D. N. (eds.), The Archaeology of Identity. Approaches to Gender, Age, Status, Ethnicity and Religion. London: Routledge.

Moore, H. 1987. Problems in the analysis of social change: an example from Marakwet, pp. 85-104 in Hodder, I. (ed.), Archaeology as Long-term History. Cambridge: Cambridge University Press. 
Murphy, E. M. 2017a. Editorial - ten years of Childhood in the Past. Childhood in the Past 10, 1-9.

Murphy, E. M. 2017b. Atypical burial practice and juvenile age-at-death in later medieval Gaelic Ireland: The evidence from Ballyhanna, Co. Donegal, pp. 227-48 in Murphy, E. and Le Roy, M. (eds.), Children, Death and Burial: Archaeological Discourses. Oxford: Oxbow Books.

Murphy, E. and Le Roy, M. 2017. Introduction: archaeological children, death and burial, pp. 1-18 in Children, Death and Burial: Archaeological Discourses. Oxford: Oxbow Books.

Nelson, S. M. 2004. Gender in Archaeology. Analyzing Power and Prestige (second edition). Walnut Creek: Altamira Press.

O'Donovan, J. 1856. Annals of The Kingdom of Ireland, by the Four Masters, from the Earliest Period to the Year 1616 (vol. 5). Dublin: Hodges, Smith, and Co.

Oestigaard, T. 2015. Changing rituals and reinventing traditions, pp. 359-77 in Brandt, J. R., Prusac, M. and Roland, H. (eds.), Death and Changing Rituals. Function and Meaning in Ancient Funerary Practices. Oxford: Oxbow Books.

Parker Pearson, M. 2003. The Archaeology of Death and Burial. Phoenix Mill: Sutton Publishing.

Ray, K. 1987. Material metaphor, social interactions and historical reconstructions: exploring patterns of association and symbolism in the Igbo-Ukwu corpus, pp. 66-77 in Hodder, I. (ed.), The Archaeology of Contextual Meaning. Cambridge: Cambridge University Press.

Ricketts, P. 2008. 'Spoiling them rotten?' Grandmothers and familial identity in twelfth- and thirteenth-century Iceland, pp. 167-204 in Lewis-Simpson, S. (ed.), Youth and Age in the Medieval North (The Northern World 42). Leiden: Brill.

Sawyer, B. and Sawyer, P. H. 1993. Medieval Scandinavia: From Conversion to Reformation, Circa 800-1500. Minneapolis: University of Minnesota Press.

Sørensen, M. L. S. 2000. Gender Archaeology. Cambridge: Polity Press.

Tringham, R. 2000. Engendered places in prehistory, pp. 32957 in Thomas, J. (ed.), Interpretative Archaeology: A Reader. London: Leicester University Press (first published in 1994 - Gender, Place and Culture 1, 169-203).

Thäte, E. S. 2007. Monuments and Minds. Monument Re-use in Scandinavia in the Second Half of the First Millennium $A D$ (Acta Archaeologica Lundensia Series in $4^{\circ}$ No. 27). Lund: Wallin \& Dalholm.

Ucko, P. J. 1969. Ethnography and archaeological interpretation of funerary remains. World Archaeology 1 , 262-80.

Welinder, S. 2001. The archaeology of old age. Current Swedish Archaeology 9, 161-77.

Yershova, Y. S. H. 2008. Egill Skalla-Grimsson: a Viking poet as a child and an old man, pp. 285-304 in Lewis-Simpson, S. (ed.), Youth and Age in the Medieval North. Leiden: Brill.

Østigård, T. (ed.) 2006. Lik og ulik. Tilncerminger til variasjon i gravskikk (UBAS - Universitetet i Bergen Arkeologiske Skrifter. Nordisk 2). Bergen: Universitetet i Bergen. 